\title{
Sediment assessment for a watershed in arid region via neural networks
}

\author{
SANDEEP SAMANTARAY* and DILLIP K GHOSE \\ Department of Civil Engineering, National Institute of Technology (NIT) Silchar, Silchar, India \\ e-mail: samantaraysandeep963@yahoo.com
}

MS received 22 May 2018; revised 17 January 2019; accepted 3 September 2019

\begin{abstract}
In the present study, the estimation of suspended sediment load is computed by four Artificial Neural Networks (ANNs) algorithms, Cascade Forward Back Propagation (CFBP), Feed Forward Back Propagation (FFBP), Radial Basis Function (RBF), and Recurrent Neural Network (RNN). Five cases of model input are calibrated to establish the relationship among precipitation, discharge and suspended sediment load. While discharge and rainfall up to four previous days as employed for input, model gives pre-eminent performance. Sensitivity of all models is appraised concerning Nash-Sutcliffe coefficient $\left(\mathrm{E}_{\mathrm{NS}}\right)$ and coefficient of determination $\left(\mathrm{R}^{2}\right)$ for predicting sediment load. Among all ANNs, MMF (Morgan-Morgan-Finney) model when trained with stream flow as the input in RNN, gives best result with coefficient of determination, $\mathrm{R}^{2}$ as 0.9474 , while the values for FFBP, CFBP and RBF are 0.9115, 0.8766 and 0.8511 , respectively. Performance of all results show that an MMF model is superior to conventional SRC (Sediment Rating Curve) and MLR (Multiple Linear Regression) models in determining the complex relationship between discharge and suspended sediment load.
\end{abstract}

Keywords. MMF; MLR; neural network; precipitation; SRC; suspended sediment; regression.

\section{Introduction}

For water resources design, management, and planning, sedimentation is a significant problem. Sediment management requires a balance with in sediment transport, sediment inflow and outflow. A part of the stream flow is the sediment load in suspension, during transport of sediment in a catchment. Exact inference of sediment quantity conceded by stream is vital for numerous water resources scheme. Forecast of suspended sediment in the watershed comprises an essential subject in hydrology and hydraulic engineering. Slope, precipitation, soil characteristics, runoff, and land use pattern affect quantity of sediment load. To have models with simulation of sediment load from discharge and precipitation is the way towards economic preference.

The suggested hydrological models engage physical uniqueness varies from black box models to substantial models [1]. SRC and MLR are commonly exercised for sediment modeling [2]. Runoff-sediment yield of watershed is a multifaceted hydrological fact. ANN is performed through black box modeling tools in hydrology [3-6]. ANN algorithms are used for sediment modeling [7-11]. They proposed FF BPNN for computing sediment concentration of catchment [12]. Wavelet and ANN techniques are proposed for foretelling sediment load considering gauge data. Three alternative models have been presented by [13] using ANNs with

*For correspondence

Published online: 04 October 2019 pattern recognition methodology for catchment. Uncertainty of sediment yield is computed by probability distribution for estimating sediment yield [14]. TRMM (Tropical Rainfall Measuring Mission) data from precipitation is useful for envisaging suspended sediment $[15,16]$. BPNN and regression model are utilized for prediction of suspended sediment load [17]. Integrated data system enhances accuracy for calculating sediment concentration. Various types of ANN models are used to forecast sediment load [18, 19].

From literature review, several researchers predicted sediment concentration but MMF model approach was not considered earlier with ANN. So, in this study, three models, namely power model SRC, MMF and MLR are developed to compute sediment load at the gauging station. Various combinations of stream flow and rainfall are made as inputs for setting suspended sediment load as the target, in FFBP, CFBP, RNN and RBF of ANNs. Each of the three models describes the relationship between the sediment load (obtained after training in these four different neural networks) and the discharge.

\section{Study area}

Salebhata watershed (figure 1) of Mahanadi basin is selected as the study area, located at $20^{\circ} 52^{\prime} 0^{\prime \prime} \mathrm{N} 83^{\circ} 31^{\prime} 0^{\prime \prime} \mathrm{E}$ in the direction of Hirakud reservoir. It has an average elevation of 153 meter. Watershed incorporates 


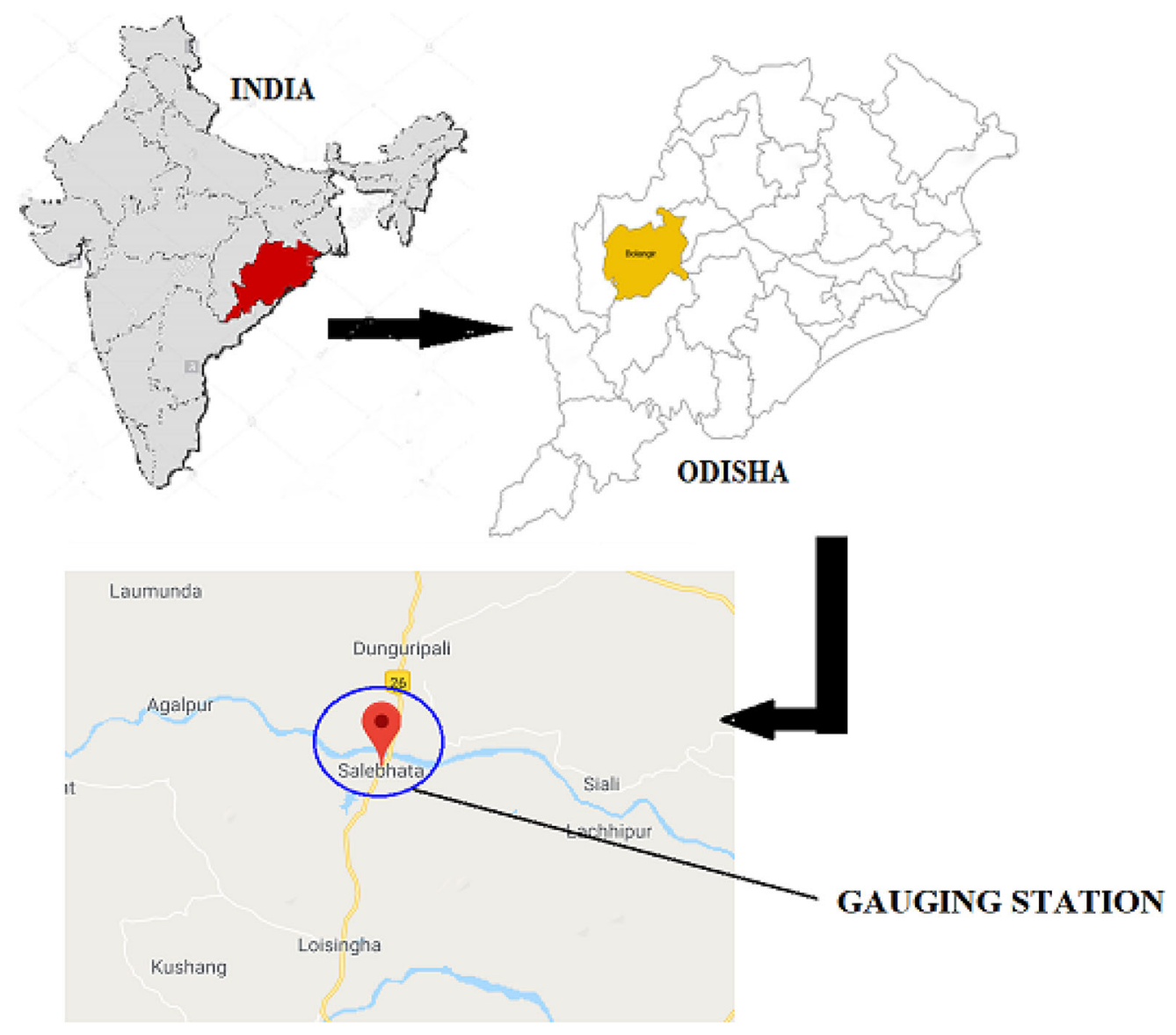

Figure 1. Study area: Salebhata watershed.

unreachable forests, river basins and hilly land. Watershed accepts serious thundershowers in May and influences humidity level. Moderate/high rainfall occurs from June to September during monsoon period, with a fluctuation of temperatures ranging from $15^{\circ} \mathrm{C}$ to $35^{\circ} \mathrm{C}$. Study is considered since the gauging station is located in arid region, which is frequently facing natural disaster due to impact of climate change.

To accomplish goal of the study, data are accumulated from IWRIS and IMD, Bhubaneswar. Daily data are brought together for a period of 25 years during monsoon period (i.e., May to October) from 1993 to 2017. Subsequently assembled data are clustered to monthly basis for analysis and model development. The data include daily rainfall, measured suspended sediment load, and water discharge for current work. One sample data for an input precipitation has been presented in figure 2 .

\section{Methodology}

ANNs are composite dispensation tools expanded through neurons to resolve precise problems. It is used for data clustering, data modeling through learning process.
Learning process is developed through synoptic connections of neurons. It is a parallel processor for accumulating testing knowledge and constructing accessible information for model development. Neural networks are defined as parameterized computational non-linear algorithm for data processing. In this information processing system signals are broadcasted by means of connecting links through correlated weight, integrated with incoming net input in terms of signal for predicting output as typical neural net. Neural network is characterized by the processes of architecture, training, and activation function. Various learning algorithm like Habb learning, Perception learning, Delta learning are used for model development. Artificial neural networks are classified depending on the training and learning pattern of neurons.

\section{$3.1 F F B P N$}

It is a systematic approach for training multilayer neurons with gradient descent algorithm for propagating error through mapping input to output. Unsupervised learning is applied for training network. The goal of the network is to train the data set for bringing a correlation between input- 


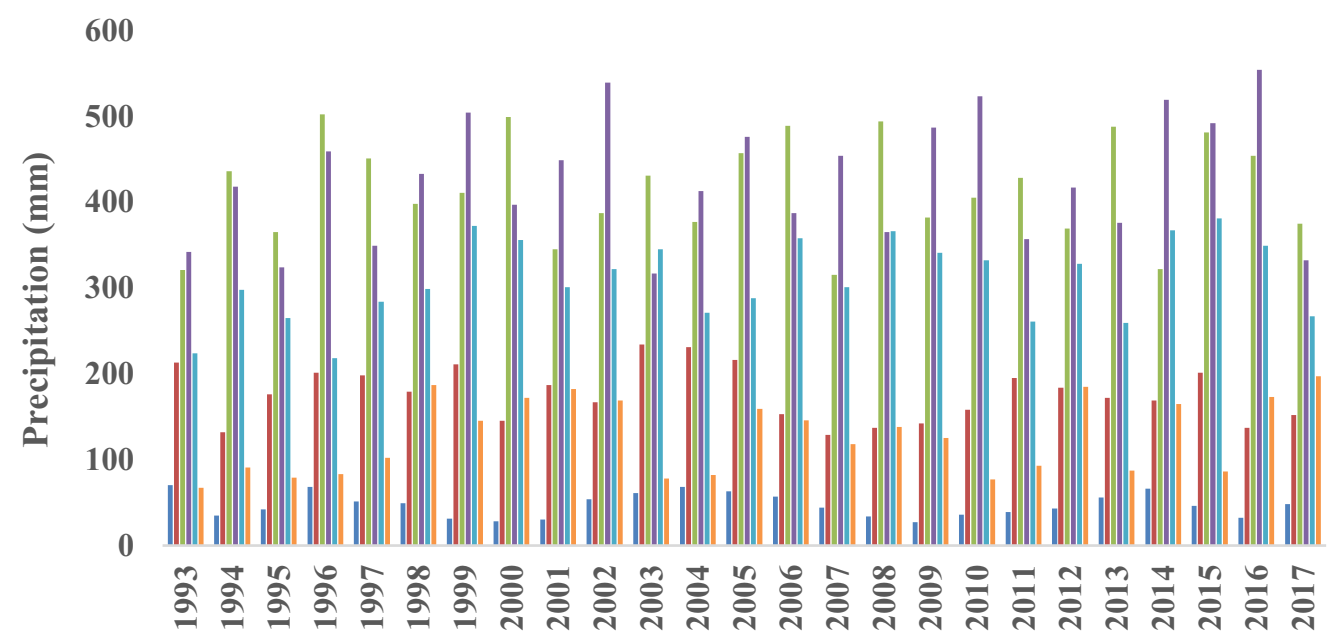

Time period (Year)

May $\quad$ June $\square$ July $\quad$ August $\quad$ September $\quad$ October

Figure 2. Variation of monthly precipitation at Salebhata (1993-2017).

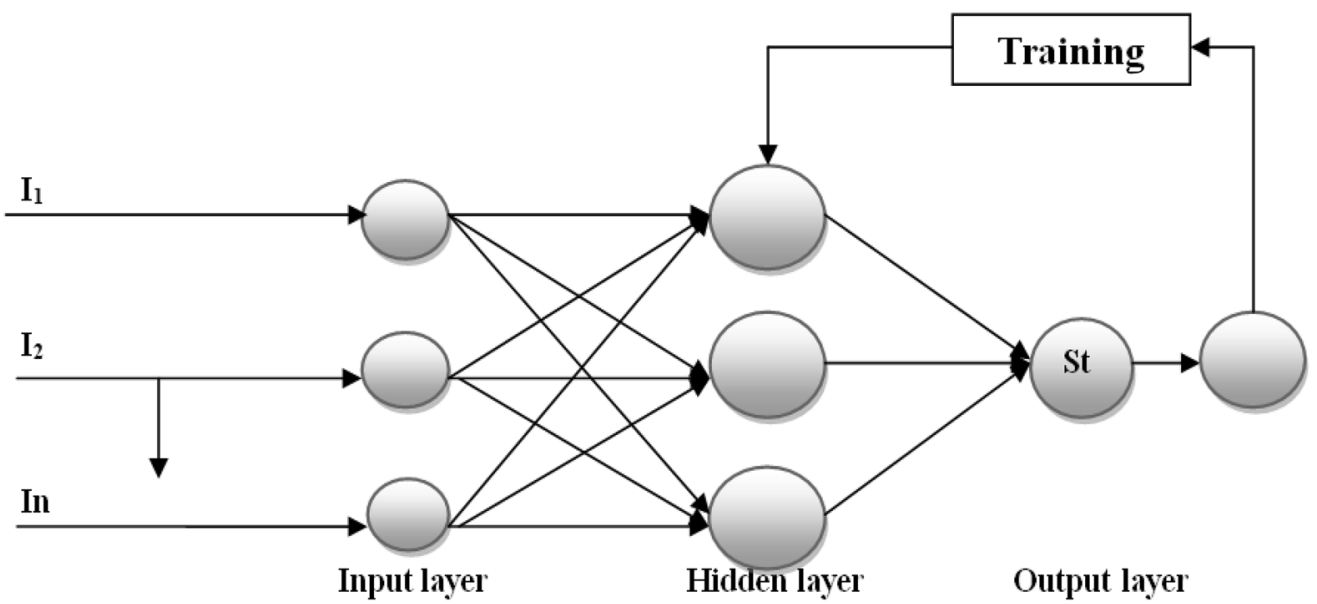

Figure 3. Back propagation neural network.

output patterns and train the network for providing good responses for model development through input-output mapping. Total squared error of output is guesstimated by net transmission of generalized delta rule. FFBPN algorithm includes initialization of weights, feed forward networks, program of errors, revision through weights and biases. For efficient operation of FFBPN, appropriate parameters are to be selected for training network. Initialization of weight is randomly chosen to fall within a range of -1 to 1 . Faster learning of FFBPN is obtained by using Nguyen-widrow (NW) initialization (figure 3).

\section{$3.2 C F B P N$}

This algorithm is selected to distinguish between FFBPN and CFBPN. It is comparable to FFBPN except the additional weight connection during parallel process of computing. Weight connections from input to hidden layer and hidden layer to successive layers before output are controlled by training to attain quick learning of the network through complex relationship. Addition of neurons is desired for achieving optimal architecture of network. Similar way training parameters are chosen for performing the mapping of CFBPN (figure 4).

\section{$3.3 R B F N$}

RBFN has three layers, mapping from input to output through nonlinear activation function.

$$
y_{j}=\sum_{i=1}^{N} w_{i} \rho\left(\left\|x-c_{i}\right\|\right)
$$

Where $y_{j}$ is the output $\mathrm{w}_{\mathrm{i}}$ is the weight 


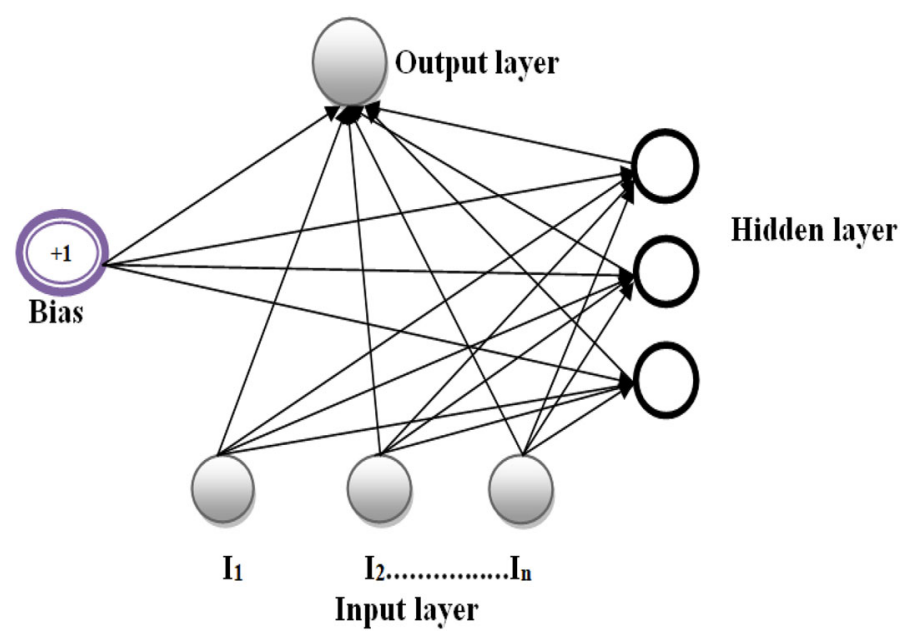

Figure 4. Cascade forward back propagation neural network.

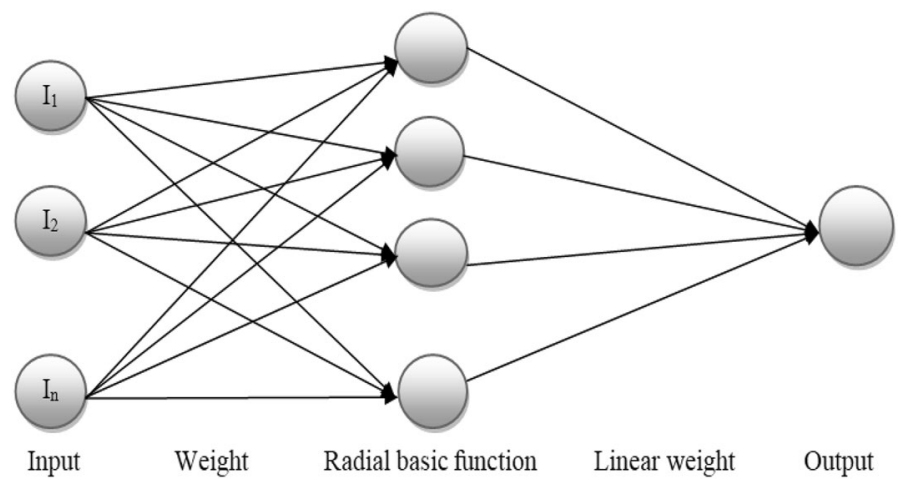

Figure 5. Radial basis function neural network.

$\rho\left(\left\|x-c_{i}\right\|\right)$ is the Gaussian function

$\mathrm{X}$ is input and $\mathrm{c}_{\mathrm{i}}$ is center vector.

The Gaussian basis function is given as

$$
\lim _{x \rightarrow \infty} \rho\left(x-c_{i}\right)=0
$$

Shifting parameters of one neuron has a little consequence for input values which are more distant from center of neuron.

With the shape of the activation function, RBF network approximate any continuous function on a closed boundary with hidden neurons to precise errors. The constraints $\mathrm{w}_{\mathrm{i}}$, $c_{i}$, are decided by optimizing the robust between $y_{j}$ and input data (figure 5).

\section{$3.4 R N N$}

RNN is an artificial neural network which has a connection between nodes from input to output through a sequence to exhibit dynamic behavior of memory input. To execute RNN, several types of algorithms are used to develop model. Elman recurrent neural network is a specific one to measure the complex nonlinear behavior of data set. Three-layered network with a set of context units fixed with weights is called Elman recurrent neural network. Input is fed-forward and a learning rule is employed in every step. Predetermined backconnections keep a replica of preceding values of hidden units in context units. Consequently, the network is a sequence prediction beyond the layer of multi-layer perceptron to perform network architecture which is described as:

$$
\begin{gathered}
\mathrm{h}_{\mathrm{t}}=\sigma_{\mathrm{h}}\left(\mathrm{W}_{\mathrm{h}} \mathrm{x}_{\mathrm{t}}+\mathrm{U}_{\mathrm{h}} \mathrm{h}_{\mathrm{t}-1}+\mathrm{b}_{\mathrm{h}}\right) \\
\mathrm{y}_{\mathrm{t}}=\sigma_{\mathrm{y}}\left(\mathrm{W}_{\mathrm{y}} \mathrm{h}_{\mathrm{t}}+\mathrm{b}_{\mathrm{y}}\right)
\end{gathered}
$$

Where,

$\mathrm{h}_{\mathrm{t}}$ : Hidden layer vector

$\mathrm{y}_{\mathrm{t}}$ : Output vector

$\mathrm{x}_{\mathrm{t}}$ : Input vector

$\mathrm{W}, \mathrm{U}, \mathrm{b}$ : parameter matrices and vector $\sigma_{\mathrm{h}}$ and $\sigma_{\mathrm{y}}$ : Activation function (figure 6). 


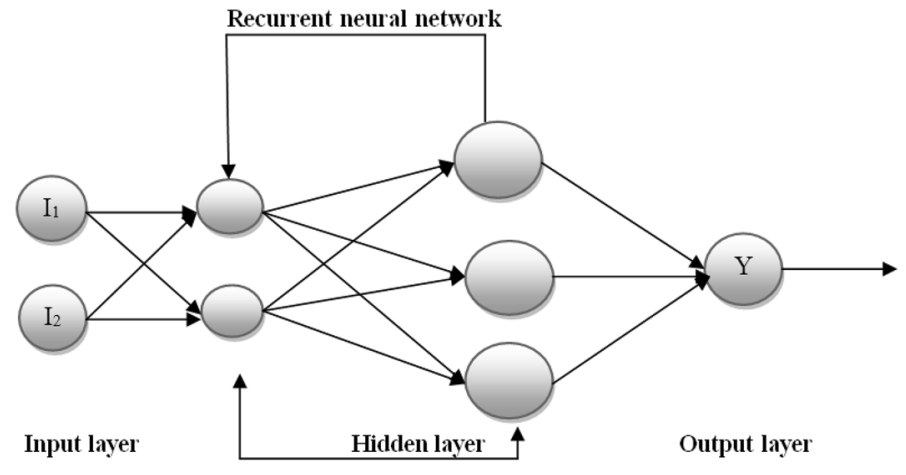

Figure 6. Recurrent neural network.

\subsection{SRC model}

A sediment rating curve relates to suspended sediment load with discharge and can be expressed as

$$
Q_{s}=a Q_{w}^{b}
$$

Where, $Q_{s}$ is suspended sediment load $\left(\mathrm{t} / \mathrm{m}^{3}\right)$, Q is discharge $\left(\mathrm{m}^{3} / \mathrm{s}\right)$, and $\mathrm{a}, \mathrm{b}$ are constants. In conjunction with flow duration curve at a given position, SRC is employed to approximate quantity of sediment transport over time period. Imperative use of SRC is to estimate impact of management and land use changes of watershed on sediment yield.

\subsection{MMF model}

Soil erosion assessment for watershed management is one of the major concerns. Morgan and Finney developed this model to predict soil loss. To estimate runoff and sediment load from a field scale on daily basis at gauging station daily data. Water and sediments from upstream surface transported through surface runoff along with eroded soils to lower slope level surfaces. Model estimates the sediment load and the surface runoff everyday and data on daily basis extended to the form of average monthly basis during monsoon period for updating the model.

$$
Q_{s}=C Q_{w}^{2}
$$

\subsection{MLR model}

Regression model which encloses numerous interpreting parameters is called MLR model. Two predictor variables are used to compile output of MLR. Least square method is applied to evaluate MLR technique. The method is well supervised with summation of squared differences between estimated and observed values.

$$
\ln Q_{s}=a_{0}+\sum_{i=1}^{n} a_{i} Q_{w}
$$

Where $Q_{s}$ : sediment load,

$Q_{w}:$ (discharge)

$a_{0}$ and $a_{i}$ : constant

\subsection{Application of ANNs to the data}

RNN, FFBP, CFBP, and RBF are employed for replications of ANN model. Several arrangements of hydro meteorological data are organized for input. $72 \%$ of data (1993-2010) are taken for training, while 28\% (2011-2017) are taken for testing purposes during monsoon period (May-October). SRC, MMF, MLR model are synchronized and fed into ANN as represented in flow chart (figure 7).

The simulation experiments that is simulating suspended sediment load are carried out in five steps: first simulation simulation using discharge up to four previous days and present day rainfall; second simulation - simulation employing discharge up to four previous days and rainfall up to one previous day; third simulation - simulation with discharge up to four previous days and rainfall up to two previous days; fourth simulation - simulation via discharge up to four previous days and rainfall up to three previous days; fifth simulation - simulation by discharge up to four previous days and rainfall up to four previous days.

For each of these simulations, $\mathrm{E}_{\mathrm{NS}}$ and $\mathrm{R}^{2}$ for the SRC are determined. The evaluating criteria to ascertain the best model are $\mathrm{R}^{2}$ and $\left(\mathrm{E}_{\mathrm{NS}}\right)$ :

$$
\mathrm{R}^{2}=\frac{\left[\sum(\mathrm{X}-\overline{\mathrm{X}})(\mathrm{Y}-\overline{\mathrm{Y}})\right]^{2}}{\sum(\mathrm{X}-\overline{\mathrm{X}})^{2} \sum(\mathrm{Y}-\overline{\mathrm{Y}})^{2}}
$$

Where, $\mathrm{X}$ : observed value

$\bar{X}$ : mean of observed values

Y: estimated value

$\bar{Y}$ : mean of estimated values

$\mathrm{N}$ : no of samples

Nash-Sutcliffe coefficient: 


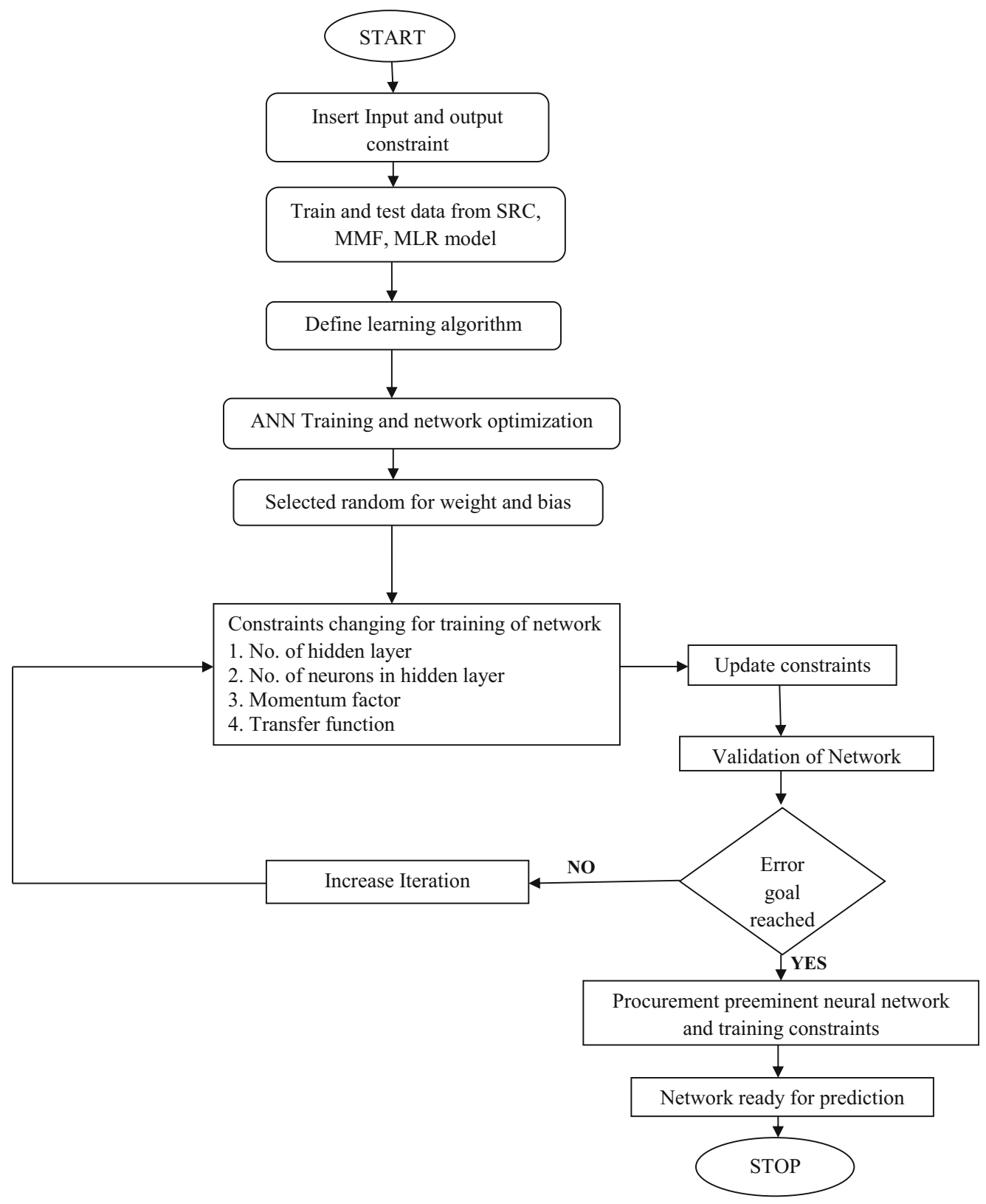

Figure 7. Flow chart for neural network.

$$
E_{N S}=1-\frac{\sum_{i=1}^{n}\left(x_{o}-x_{f}\right)^{2}}{\sum_{i=1}^{n}\left(x_{o}-\bar{x}_{o}\right)^{2}}
$$

where $\mathrm{x}_{\mathrm{o}}=$ observed data

$\mathrm{x}_{\mathrm{f}}=$ computed data

$\bar{x}_{o}=$ mean of observed data,

$\mathrm{n}=$ number of events considered

\section{Results and discussion}

Inputs in terms of present monthly discharge and lagging monthly discharge ranging from one month to four months are considered for mapping the sediment output using power model (SRC), MMF model and MLR model with FFBP, CFBP, RNN and RBFN algorithms are presented in table 1 .

\subsection{Replicating suspended sediment load using discharge as input}

An arrangement for combination of discharge with present day rainfall is made as input. Among the three models, an MMF model best catches the relationship between discharge and sediment load, for all inputs as compared to SRC and MLR in all ANNs as found in table 1. At the same time, it is found that considering $\mathrm{Q}_{\mathrm{t}}, \mathrm{Q}_{\mathrm{t}-1}, \mathrm{Q}_{\mathrm{t}-2}, \mathrm{Q}_{\mathrm{t}-3}, \mathrm{Q}_{\mathrm{t}-4}$, 
Table 1. Performance consequences of simulation one.

\begin{tabular}{|c|c|c|c|c|c|c|c|c|c|}
\hline \multirow[b]{2}{*}{ INPUTS } & \multirow[b]{2}{*}{ Model } & \multicolumn{2}{|c|}{ FFBPN } & \multicolumn{2}{|c|}{ CFBPN } & \multicolumn{2}{|c|}{ RNN } & \multicolumn{2}{|c|}{ RBFN } \\
\hline & & $\mathrm{E}_{\mathrm{NS}}$ & $\mathrm{R}^{2}$ & $\mathrm{E}_{\mathrm{NS}}$ & $\mathrm{R}^{2}$ & $\mathrm{E}_{\mathrm{NS}}$ & $\mathrm{R}^{2}$ & $\mathrm{E}_{\mathrm{NS}}$ & $\mathrm{R}^{2}$ \\
\hline $\mathrm{Q}_{\mathrm{t}}, \mathrm{P}_{\mathrm{t}}$ & & 0.5947 & 0.7712 & 0.5286 & 0.7271 & 0.6768 & 0.8227 & 0.5011 & 0.7079 \\
\hline $\mathrm{Q}_{\mathrm{t}}, \mathrm{Q}_{\mathrm{t}-1}, \mathrm{P}_{\mathrm{t}}$ & & 0.6502 & 0.8064 & 0.5765 & 0.7593 & 0.6973 & 0.8351 & 0.5175 & 0.7194 \\
\hline $\mathrm{Q}_{\mathrm{t}}, \mathrm{Q}_{\mathrm{t}-1}, \mathrm{Q}_{\mathrm{t}-2,}, \mathrm{P}_{\mathrm{t}}$ & SRC & 0.6612 & 0.8132 & 0.5904 & 0.7684 & 0.7349 & 0.8573 & 0.5667 & 0.7528 \\
\hline $\mathrm{Q}_{\mathrm{t}}, \mathrm{Q}_{\mathrm{t}-1}, \mathrm{Q}_{\mathrm{t}-2}, \mathrm{Q}_{\mathrm{t}-3}, \mathrm{P}_{\mathrm{t}}$ & & 0.7255 & 0.8518 & 0.6274 & 0.7921 & 0.7677 & 0.8762 & 0.5949 & 0.7713 \\
\hline $\mathrm{Q}_{\mathrm{t}}, \mathrm{Q}_{\mathrm{t}-1}, \mathrm{Q}_{\mathrm{t}-2}, \mathrm{Q}_{\mathrm{t}-3}, \mathrm{Q}_{\mathrm{t}-4}, \mathrm{P}_{\mathrm{t}}$ & & 0.7399 & 0.8602 & 0.6554 & 0.8096 & 0.7853 & 0.8862 & 0.6296 & 0.7935 \\
\hline $\mathrm{Q}_{\mathrm{t}}, \mathrm{P}_{\mathrm{t}}$ & & 0.6341 & 0.7963 & 0.5516 & 0.7427 & 0.7135 & 0.8447 & 0.5286 & 0.7271 \\
\hline $\mathrm{Q}_{\mathrm{t}}, \mathrm{Q}_{\mathrm{t}-1}, \mathrm{P}_{\mathrm{t}}$ & & 0.6705 & 0.8189 & 0.5973 & 0.7729 & 0.7385 & 0.8594 & 0.5569 & 0.7463 \\
\hline $\mathrm{Q}_{\mathrm{t}}, \mathrm{Q}_{\mathrm{t}-1}, \mathrm{Q}_{\mathrm{t}-2,}, \mathrm{P}_{\mathrm{t}}$ & MMF & 0.6728 & 0.8203 & 0.6233 & 0.7895 & 0.7609 & 0.8723 & 0.5667 & 0.7528 \\
\hline $\mathrm{Q}_{\mathrm{t}}, \mathrm{Q}_{\mathrm{t}-1}, \mathrm{Q}_{\mathrm{t}-2}, \mathrm{Q}_{\mathrm{t}-3}, \mathrm{P}_{\mathrm{t}}$ & & 0.6935 & 0.8328 & 0.6277 & 0.7923 & 0.7842 & 0.8856 & 0.6148 & 0.7841 \\
\hline $\mathrm{Q}_{\mathrm{t}}, \mathrm{Q}_{\mathrm{t}-1}, \mathrm{Q}_{\mathrm{t}-2}, \mathrm{Q}_{\mathrm{t}-3}, \mathrm{Q}_{\mathrm{t}-4}, \mathrm{P}_{\mathrm{t}}$ & & 0.7591 & 0.8713 & 0.6683 & 0.8175 & 0.8058 & 0.8977 & 0.6454 & 0.8034 \\
\hline $\mathrm{Q}_{\mathrm{t}}, \mathrm{P}_{\mathrm{t}}$ & & 0.5015 & 0.7082 & 0.5036 & 0.7097 & 0.5750 & 0.7583 & 0.4946 & 0.7033 \\
\hline $\mathrm{Q}_{\mathrm{t}}, \mathrm{Q}_{\mathrm{t}-1}, \mathrm{P}_{\mathrm{t}}$ & & 0.5838 & 0.7641 & 0.5449 & 0.7382 & 0.6108 & 0.7816 & 0.5022 & 0.7087 \\
\hline $\mathrm{Q}_{\mathrm{t}}, \mathrm{Q}_{\mathrm{t}-1}, \mathrm{Q}_{\mathrm{t}-2}, \mathrm{P}_{\mathrm{t}}$ & MLR & 0.6425 & 0.8016 & 0.5689 & 0.7543 & 0.6925 & 0.8322 & 0.5378 & 0.7334 \\
\hline $\mathrm{Q}_{\mathrm{t}}, \mathrm{Q}_{\mathrm{t}-1}, \mathrm{Q}_{\mathrm{t}-2}, \mathrm{Q}_{\mathrm{t}-3}, \mathrm{P}_{\mathrm{t}}$ & & 0.6647 & 0.8153 & 0.5945 & 0.7711 & 0.7192 & 0.8481 & 0.5680 & 0.7537 \\
\hline $\mathrm{Q}_{\mathrm{t}}, \mathrm{Q}_{\mathrm{t}-1}, \mathrm{Q}_{\mathrm{t}-2,}, \mathrm{Q}_{\mathrm{t}-3}, \mathrm{Q}_{\mathrm{t}-4}, \mathrm{P}_{\mathrm{t}}$ & & 0.6957 & 0.8341 & 0.6242 & 0.7901 & 0.7349 & 0.8573 & 0.5938 & 0.7706 \\
\hline
\end{tabular}

$\mathrm{P}_{\mathrm{t}}$, as input, model performs best with $\mathrm{R}^{2}$ value as 0.8977 when trained RNN algorithm, while the corresponding values in power model and MLR are 0.8862 and 0.8573 , respectively. It is established from the results that an MMF model is enhanced to conventional SRC models and MLR models in determining the multifaceted correlation between suspended sediment load and discharge.

\subsection{Simulating suspended sediment load using discharge and rainfall up to one previous day}

In this part of study, the discharge up to four previous days along with the rainfall up to one previous day are set as inputs in various combinations. These inputs are trained with all the four algorithms and then they are put into the models to obtain the corresponding Nash-Sutcliffe coefficient and coefficient of determination.

From the results obtained by training these combination of inputs in various algorithms and then comparing them among various models, it is established that when $\mathrm{Q}_{t}, \mathrm{Q}_{\mathrm{t}-1}$, $\mathrm{Q}_{\mathrm{t}-2,}, \mathrm{Q}_{\mathrm{t}-3,}, \mathrm{Q}_{\mathrm{t}-4}, \mathrm{P}_{\mathrm{t}}, \mathrm{P}_{\mathrm{t}-1}$ are feed as inputs, then the best result is obtained by training the inputs in RNN with the model efficiency of 0.9039 and relationship between suspended sediment and discharge is best depicted in an MMF model. For all models, performance of MMF is superior to SRC and MLR as presented in table 2.

\subsection{Simulating suspended sediment load using discharge and rainfall up to two previous days}

In this part of study, the discharge up to four previous days along with the rainfall up to two previous day are set as inputs in various combinations. These combinations of inputs are trained in various algorithms. The output, which is set as suspended sediment is then contrasted with the discharge, to gain a relation in various models (table 3 ).

From the results obtained by training these combination of inputs in various algorithms and then comparing them among various models, it can be established that $\mathrm{Q}_{\mathrm{t}}, \mathrm{Q}_{\mathrm{t}-1}$, $\mathrm{Q}_{\mathrm{t}-2,}, \mathrm{Q}_{\mathrm{t}-3}, \mathrm{Q}_{\mathrm{t}-4}, \mathrm{P}_{\mathrm{t}}, \mathrm{P}_{\mathrm{t}-1}, \mathrm{P}_{\mathrm{t}-2}$ yield the best result in establishing the association between sediment load and discharge. Here, an MMF model works out to be superior to other models and the best result in this combination is yielded when the inputs of the combination is trained in RNN algorithm. The obtained value of $\mathrm{R}^{2}$ is 0.9153 in MMF model, while the corresponding value in power model and MLR are 0.9142 and 0.8874 , respectively.

\subsection{Simulating suspended sediment load using discharge and up to three day lag rainfall}

In this part of study, the discharge up to four previous days along with the rainfall up to three days are set as inputs in various combinations. These combinations of inputs are trained in various algorithms. The output, which is set as suspended sediment is then contrasted with the discharge, to obtain the link between discharge and sediment, in various models (table 4).

From the results obtained by training these combination of inputs in various algorithms and then comparing them among various models, it can be established that when $\mathrm{Q}_{\mathrm{t}}$, $\mathrm{Q}_{\mathrm{t}-1}, \mathrm{Q}_{\mathrm{t}-2,}, \mathrm{Q}_{\mathrm{t}-3}, \mathrm{Q}_{\mathrm{t}-4}, \mathrm{P}_{\mathrm{t}}, \mathrm{P}_{\mathrm{t}-1}, \mathrm{P}_{\mathrm{t}-2}, \mathrm{P}_{\mathrm{t}-3}$ yield consistency between sediment and discharge. The best value of $\mathrm{R}^{2}$ so obtained is 0.9364 in MMF model when trained in RNN algorithm. The corresponding values in power model and the MLR, when trained in the same algorithm are 0.9295 and 0.9084 . 
Table 2. Performance consequences of simulation two.

\begin{tabular}{|c|c|c|c|c|c|c|c|c|c|}
\hline \multirow[b]{2}{*}{ INPUTS } & \multirow[b]{2}{*}{ Model } & \multicolumn{2}{|c|}{ FFBPN } & \multicolumn{2}{|c|}{ CFBPN } & \multicolumn{2}{|c|}{ RNN } & \multicolumn{2}{|c|}{ RBFN } \\
\hline & & $\mathrm{E}_{\mathrm{NS}}$ & $\mathrm{R}^{2}$ & $\mathrm{E}_{\mathrm{NS}}$ & $\mathrm{R}^{2}$ & $\mathrm{E}_{\mathrm{NS}}$ & $\mathrm{R}^{2}$ & $\mathrm{E}_{\mathrm{NS}}$ & $\mathrm{R}^{2}$ \\
\hline $\mathrm{Q}_{\mathrm{t}}, \mathrm{P}_{\mathrm{t},} \mathrm{P}_{\mathrm{t}-1}$ & & 0.6085 & 0.7801 & 0.5464 & 0.7392 & 0.6991 & 0.8361 & 0.5179 & 0.7197 \\
\hline $\mathrm{Q}_{\mathrm{t}}, \mathrm{Q}_{\mathrm{t}-1}, \mathrm{P}_{\mathrm{t}}, \mathrm{P}_{\mathrm{t}-1}$ & & 0.6784 & 0.8237 & 0.5879 & 0.7668 & 0.7084 & 0.8417 & 0.5421 & 0.7363 \\
\hline $\mathrm{Q}_{\mathrm{t}}, \mathrm{Q}_{\mathrm{t}-1}, \mathrm{Q}_{\mathrm{t}-2,}, \mathrm{P}_{\mathrm{t}}, \mathrm{P}_{\mathrm{t}-1}$ & $\mathrm{SRC}$ & 0.6975 & 0.8352 & 0.6176 & 0.7859 & 0.7546 & 0.8687 & 0.5847 & 0.7647 \\
\hline$Q_{t}, Q_{t-1}, Q_{t-2}, Q_{t-3}, P_{t}, P_{t-1}$ & & 0.7497 & 0.8659 & 0.6497 & 0.8061 & 0.7809 & 0.8837 & 0.6323 & 0.7952 \\
\hline $\mathrm{Q}_{\mathrm{t}}, \mathrm{Q}_{\mathrm{t}-1}, \mathrm{Q}_{\mathrm{t}-2,}, \mathrm{Q}_{\mathrm{t}-3,}, \mathrm{Q}_{\mathrm{t}-4}, \mathrm{P}_{\mathrm{t}}, \mathrm{P}_{\mathrm{t}-1}$ & & 0.7773 & 0.8817 & 0.6689 & 0.8179 & 0.8083 & 0.8991 & 0.6515 & 0.8072 \\
\hline $\mathrm{Q}_{\mathrm{t}}, \mathrm{P}_{\mathrm{t}}, \mathrm{P}_{\mathrm{t}-1}$ & & 0.6461 & 0.8038 & 0.5725 & 0.7567 & 0.7248 & 0.8514 & 0.5339 & 0.7307 \\
\hline $\mathrm{Q}_{\mathrm{t}}, \mathrm{Q}_{\mathrm{t}-1}, \mathrm{P}_{\mathrm{t}}, \mathrm{P}_{\mathrm{t}-1}$ & & 0.6874 & 0.8291 & 0.6176 & 0.7859 & 0.7515 & 0.8669 & 0.5659 & 0.7523 \\
\hline $\mathrm{Q}_{\mathrm{t}}, \mathrm{Q}_{\mathrm{t}-1,}, \mathrm{Q}_{\mathrm{t}-2,}, \mathrm{P}_{\mathrm{t}}, \mathrm{P}_{\mathrm{t}-1}$ & MMF & 0.7169 & 0.8467 & 0.6404 & 0.8003 & 0.7773 & 0.8817 & 0.5815 & 0.7626 \\
\hline $\mathrm{Q}_{\mathrm{t}}, \mathrm{Q}_{\mathrm{t}-1}, \mathrm{Q}_{\mathrm{t}-2,}, \mathrm{Q}_{\mathrm{t}-3,}, \mathrm{P}_{\mathrm{t}}, \mathrm{P}_{\mathrm{t}-1}$ & & 0.7291 & 0.8539 & 0.6539 & 0.8087 & 0.8076 & 0.8987 & 0.6315 & 0.7947 \\
\hline $\mathrm{Q}_{\mathrm{t}}, \mathrm{Q}_{\mathrm{t}-1}, \mathrm{Q}_{\mathrm{t}-2}, \mathrm{Q}_{\mathrm{t}-3,}, \mathrm{Q}_{\mathrm{t}-4}, \mathrm{P}_{\mathrm{t}}, \mathrm{P}_{\mathrm{t}-1}$ & & 0.7679 & 0.8763 & 0.6766 & 0.8226 & 0.8171 & 0.9039 & 0.6671 & 0.8168 \\
\hline $\mathrm{Q}_{\mathrm{t}}, \mathrm{P}_{\mathrm{t},} \mathrm{P}_{\mathrm{t}-1}$ & & 0.5063 & 0.7116 & 0.5115 & 0.7152 & 0.5788 & 0.7608 & 0.5075 & 0.7124 \\
\hline $\mathrm{Q}_{\mathrm{t}}, \mathrm{Q}_{\mathrm{t}-1}, \mathrm{P}_{\mathrm{t}}, \mathrm{P}_{\mathrm{t}-1}$ & & 0.6263 & 0.7914 & 0.5617 & 0.7495 & 0.6424 & 0.8015 & 0.5394 & 0.7345 \\
\hline $\mathrm{Q}_{\mathrm{t}}, \mathrm{Q}_{\mathrm{t}-1}, \mathrm{Q}_{\mathrm{t}-2,}, \mathrm{P}_{\mathrm{t}}, \mathrm{P}_{\mathrm{t}-1}$ & MLR & 0.6608 & 0.8129 & 0.5884 & 0.7671 & 0.7213 & 0.8493 & 0.5536 & 0.7441 \\
\hline $\mathrm{Q}_{\mathrm{t}}, \mathrm{Q}_{\mathrm{t}-1}, \mathrm{Q}_{\mathrm{t}-2,}, \mathrm{Q}_{\mathrm{t}-3}, \mathrm{P}_{\mathrm{t}}, \mathrm{P}_{\mathrm{t}-1}$ & & 0.7027 & 0.8383 & 0.6217 & 0.7885 & 0.7335 & 0.8565 & 0.5815 & 0.7626 \\
\hline $\mathrm{Q}_{\mathrm{t}}, \mathrm{Q}_{\mathrm{t}-1}, \mathrm{Q}_{\mathrm{t}-2}, \mathrm{Q}_{\mathrm{t}-3,}, \mathrm{Q}_{\mathrm{t}-4}, \mathrm{P}_{\mathrm{t}}, \mathrm{P}_{\mathrm{t}-1}$ & & 0.7265 & 0.8524 & 0.6459 & 0.8037 & 0.7425 & 0.8617 & 0.6211 & 0.7881 \\
\hline
\end{tabular}

Table 3. Performance consequences of simulation three.

\begin{tabular}{|c|c|c|c|c|c|c|c|c|c|}
\hline \multirow[b]{2}{*}{ INPUTS } & \multirow[b]{2}{*}{ Model } & \multicolumn{2}{|c|}{ FFBPN } & \multicolumn{2}{|c|}{ CFBPN } & \multicolumn{2}{|c|}{ RNN } & \multicolumn{2}{|c|}{ RBFN } \\
\hline & & $\mathrm{E}_{\mathrm{NS}}$ & $\mathrm{R}^{2}$ & $\mathrm{E}_{\mathrm{NS}}$ & $\mathrm{R}^{2}$ & $\mathrm{E}_{\mathrm{NS}}$ & $\mathrm{R}^{2}$ & $\mathrm{E}_{\mathrm{NS}}$ & $\mathrm{R}^{2}$ \\
\hline $\mathrm{Q}_{\mathrm{t},} \mathrm{P}_{\mathrm{t},} \mathrm{P}_{\mathrm{t}-1}, \mathrm{P}_{\mathrm{t}-2}$ & & 0.6258 & 0.7911 & 0.5568 & 0.7462 & 0.7213 & 0.8493 & 0.5311 & 0.7287 \\
\hline $\mathrm{Q}_{\mathrm{t}}, \mathrm{Q}_{\mathrm{t}-1}, \mathrm{P}_{\mathrm{t}}, \mathrm{P}_{\mathrm{t}-1}, \mathrm{P}_{\mathrm{t}-2}$ & & 0.6997 & 0.8365 & 0.6137 & 0.7834 & 0.7298 & 0.8543 & 0.5523 & 0.7431 \\
\hline $\mathrm{Q}_{\mathrm{t}}, \mathrm{Q}_{\mathrm{t}-1}, \mathrm{Q}_{\mathrm{t}-2}, \mathrm{P}_{\mathrm{t},}, \mathrm{P}_{\mathrm{t}-1}, \mathrm{P}_{\mathrm{t}-2}$ & SRC & 0.7522 & 0.8673 & 0.6372 & 0.7983 & 0.7624 & 0.8732 & 0.6138 & 0.7835 \\
\hline $\mathrm{Q}_{\mathrm{t}}, \mathrm{Q}_{\mathrm{t}-1}, \mathrm{Q}_{\mathrm{t}-2}, \mathrm{Q}_{\mathrm{t}-3}, \mathrm{P}_{\mathrm{t}}, \mathrm{P}_{\mathrm{t}-1}, \mathrm{P}_{\mathrm{t}-2}$ & & 0.7681 & 0.8764 & 0.6617 & 0.8135 & 0.7947 & 0.8915 & 0.6522 & 0.8075 \\
\hline $\mathrm{Q}_{\mathrm{t}}, \mathrm{Q}_{\mathrm{t}-1}, \mathrm{Q}_{\mathrm{t}-2}, \mathrm{Q}_{\mathrm{t}-3}, \mathrm{Q}_{\mathrm{t}-4}, \mathrm{P}_{\mathrm{t}}, \mathrm{P}_{\mathrm{t}-1}, \mathrm{P}_{\mathrm{t}-2}$ & & 0.7933 & 0.8907 & 0.6779 & 0.8234 & 0.8357 & 0.9142 & 0.6604 & 0.8127 \\
\hline $\mathrm{Q}_{\mathrm{t}}, \mathrm{P}_{\mathrm{t},} \mathrm{P}_{\mathrm{t}-1}, \mathrm{P}_{\mathrm{t}-2}$ & & 0.6709 & 0.8191 & 0.5879 & 0.7668 & 0.7548 & 0.8688 & 0.5763 & 0.7592 \\
\hline $\mathrm{Q}_{\mathrm{t}}, \mathrm{Q}_{\mathrm{t}-1}, \mathrm{P}_{\mathrm{t}}, \mathrm{P}_{\mathrm{t}-1}, \mathrm{P}_{\mathrm{t}-2}$ & & 0.7175 & 0.8471 & 0.6313 & 0.7946 & 0.7617 & 0.8728 & 0.5836 & 0.7636 \\
\hline $\mathrm{Q}_{\mathrm{t}}, \mathrm{Q}_{\mathrm{t}-1}, \mathrm{Q}_{\mathrm{t}-2}, \mathrm{P}_{\mathrm{t}}, \mathrm{P}_{\mathrm{t}-1}, \mathrm{P}_{\mathrm{t}-2}$ & MMF & 0.7537 & 0.8682 & 0.6648 & 0.8154 & 0.8004 & 0.8947 & 0.6248 & 0.7905 \\
\hline $\mathrm{Q}_{\mathrm{t}}, \mathrm{Q}_{\mathrm{t}-1}, \mathrm{Q}_{\mathrm{t}-2}, \mathrm{Q}_{\mathrm{t}-3}, \mathrm{P}_{\mathrm{t}}, \mathrm{P}_{\mathrm{t}-1}, \mathrm{P}_{\mathrm{t}-2}$ & & 0.7421 & 0.8615 & 0.6722 & 0.8199 & 0.8271 & 0.9094 & 0.6704 & 0.8188 \\
\hline $\mathrm{Q}_{\mathrm{t}}, \mathrm{Q}_{\mathrm{t}-1}, \mathrm{Q}_{\mathrm{t}-2,}, \mathrm{Q}_{\mathrm{t}-3}, \mathrm{Q}_{\mathrm{t}-4}, \mathrm{P}_{\mathrm{t}}, \mathrm{P}_{\mathrm{t}-1}, \mathrm{P}_{\mathrm{t}-2}$ & & 0.8013 & 0.8952 & 0.6995 & 0.8364 & $\mathbf{0 . 8 3 7 7}$ & 0.9153 & 0.6875 & 0.8292 \\
\hline $\mathrm{Q}_{\mathrm{t}}, \mathrm{P}_{\mathrm{t},} \mathrm{P}_{\mathrm{t}-1}, \mathrm{P}_{\mathrm{t}-2}$ & & 0.5294 & 0.7276 & 0.5252 & 0.7246 & 0.6116 & 0.7821 & 0.5266 & 0.7257 \\
\hline $\mathrm{Q}_{\mathrm{t}}, \mathrm{Q}_{\mathrm{t}-1}, \mathrm{P}_{\mathrm{t}}, \mathrm{P}_{\mathrm{t}-1}, \mathrm{P}_{\mathrm{t}-2}$ & & 0.6404 & 0.8003 & 0.5713 & 0.7559 & 0.6631 & 0.8143 & 0.5526 & 0.7434 \\
\hline $\mathrm{Q}_{\mathrm{t}}, \mathrm{Q}_{\mathrm{t}-1}, \mathrm{Q}_{\mathrm{t}-2}, \mathrm{P}_{\mathrm{t}}, \mathrm{P}_{\mathrm{t}-1}, \mathrm{P}_{\mathrm{t}-2}$ & MLR & 0.6743 & 0.8212 & 0.6048 & 0.7777 & 0.7228 & 0.8502 & 0.5759 & 0.7589 \\
\hline $\mathrm{Q}_{\mathrm{t}}, \mathrm{Q}_{\mathrm{t}-1}, \mathrm{Q}_{\mathrm{t}-2}, \mathrm{Q}_{\mathrm{t}-3}, \mathrm{P}_{\mathrm{t}}, \mathrm{P}_{\mathrm{t}-1}, \mathrm{P}_{\mathrm{t}-2}$ & & 0.7162 & 0.8463 & 0.6242 & 0.7901 & 0.7668 & 0.8757 & 0.6173 & 0.7857 \\
\hline $\mathrm{Q}_{\mathrm{t}}, \mathrm{Q}_{\mathrm{t}-1}, \mathrm{Q}_{\mathrm{t}-2,}, \mathrm{Q}_{\mathrm{t}-3,}, \mathrm{Q}_{\mathrm{t}-4}, \mathrm{P}_{\mathrm{t}}, \mathrm{P}_{\mathrm{t}-1}, \mathrm{P}_{\mathrm{t}-2}$ & & 0.7466 & 0.8641 & 0.6712 & 0.8193 & 0.7874 & 0.8874 & 0.6387 & 0.7992 \\
\hline
\end{tabular}

\subsection{Simulating suspended sediment load using discharge and up to four day lag rainfall}

In this part of study, the discharges up to four previous days along with the rainfall up to previous four days are considered as inputs in various combinations. These combinations of inputs are trained in various algorithms. The output, which is set as suspended sediment is then contrasted with the discharge in various models.

From the results obtained by training the combination of inputs in various algorithms is established that when $\mathrm{Q}_{\mathrm{t}}$, $\mathrm{Q}_{\mathrm{t}-1}, \mathrm{Q}_{\mathrm{t}-2,}, \mathrm{Q}_{\mathrm{t}-3}, \mathrm{Q}_{\mathrm{t}-4}, \mathrm{P}_{\mathrm{t}}, \mathrm{P}_{\mathrm{t}-1}, \mathrm{P}_{\mathrm{t}-2}, \mathrm{P}_{\mathrm{t}-3}, \mathrm{P}_{\mathrm{t}-4}$ are combined, then the best result is obtained. The best result in this simulation is shown by MMF model when trained in RNN with $\mathrm{R}^{2}$ value as 0.9474 . Whereas, the corresponding $\mathrm{R}^{2}$ value when trained in the same network, in power model and MLR are 0.9383 and 0.9192 , respectively. MMF model while trained with various inputs as cited in table 5 performs better for all ANNs as compared to the performances of SRC and MLR.

\subsection{Analysis}

For simulation, one discharge along with the rainfall of day's $\mathrm{t}, \mathrm{t}-1, \mathrm{t}-2, \mathrm{t}-3$ and $\mathrm{t}-4$ are combined, then best 
Table 4. Performance consequences of simulation four.

\begin{tabular}{|c|c|c|c|c|c|c|c|c|c|}
\hline \multirow[b]{2}{*}{ INPUTS } & \multirow[b]{2}{*}{ Model } & \multicolumn{2}{|c|}{ FFBPN } & \multicolumn{2}{|c|}{ CFBPN } & \multicolumn{2}{|c|}{ RNN } & \multicolumn{2}{|c|}{ RBFN } \\
\hline & & $\mathrm{E}_{\mathrm{NS}}$ & $\mathrm{R}^{2}$ & $\mathrm{E}_{\mathrm{NS}}$ & $\mathrm{R}^{2}$ & $\mathrm{E}_{\mathrm{NS}}$ & $\mathrm{R}^{2}$ & $\mathrm{E}_{\mathrm{NS}}$ & $\mathrm{R}^{2}$ \\
\hline $\mathrm{Q}_{\mathrm{t}}, \mathrm{P}_{\mathrm{t},} \mathrm{P}_{\mathrm{t}-1,}, \mathrm{P}_{\mathrm{t}-2,}, \mathrm{P}_{\mathrm{t}-3}$ & & 0.6451 & 0.8032 & 0.5771 & 0.7597 & 0.7342 & 0.8569 & 0.5337 & 0.7306 \\
\hline $\mathrm{Q}_{\mathrm{t}}, \mathrm{Q}_{\mathrm{t}-1}, \mathrm{P}_{\mathrm{t}}, \mathrm{P}_{\mathrm{t}-1}, \mathrm{P}_{\mathrm{t}-2}, \mathrm{P}_{\mathrm{t}-3}$ & & 0.7218 & 0.8496 & 0.6277 & 0.7923 & 0.7454 & 0.8634 & 0.5754 & 0.7586 \\
\hline $\mathrm{Q}_{\mathrm{t}}, \mathrm{Q}_{\mathrm{t}-1}, \mathrm{Q}_{\mathrm{t}-2,}, \mathrm{P}_{\mathrm{t}}, \mathrm{P}_{\mathrm{t}-1}, \mathrm{P}_{\mathrm{t}-2,}, \mathrm{P}_{\mathrm{t}-3}$ & SRC & 0.7711 & 0.8781 & 0.6478 & 0.8049 & 0.7842 & 0.8856 & 0.6253 & 0.7908 \\
\hline $\mathrm{Q}_{\mathrm{t}}, \mathrm{Q}_{\mathrm{t}-1}, \mathrm{Q}_{\mathrm{t}-2,}, \mathrm{Q}_{\mathrm{t}-3}, \mathrm{P}_{\mathrm{t}}, \mathrm{P}_{\mathrm{t}-1}, \mathrm{P}_{\mathrm{t}-2}, \mathrm{P}_{\mathrm{t}-3}$ & & 0.7848 & 0.8859 & 0.6935 & 0.8328 & 0.8137 & 0.9021 & 0.6603 & 0.8126 \\
\hline $\mathrm{Q}_{\mathrm{t}}, \mathrm{Q}_{\mathrm{t}-1}, \mathrm{Q}_{\mathrm{t}-2}, \mathrm{Q}_{\mathrm{t}-3}, \mathrm{Q}_{\mathrm{t}-4}, \mathrm{P}_{\mathrm{t}}, \mathrm{P}_{\mathrm{t}-1}, \mathrm{P}_{\mathrm{t}-2}, \mathrm{P}_{\mathrm{t}-3}$ & & 0.7985 & 0.8936 & 0.7317 & 0.8554 & 0.8639 & 0.9295 & 0.6903 & 0.8309 \\
\hline $\mathrm{Q}_{\mathrm{t},} \mathrm{P}_{\mathrm{t}}, \mathrm{P}_{\mathrm{t}-1}, \mathrm{P}_{\mathrm{t}-2,}, \mathrm{P}_{\mathrm{t}-3}$ & & 0.6985 & 0.8358 & 0.5976 & 0.7731 & 0.7681 & 0.8764 & 0.5971 & 0.7727 \\
\hline$Q_{t}, Q_{t-1}, P_{t}, P_{t-1}, P_{t-2}, P_{t-3}$ & & 0.7322 & 0.8557 & 0.6468 & 0.8043 & 0.7878 & 0.8876 & 0.6212 & 0.7882 \\
\hline $\mathrm{Q}_{\mathrm{t}}, \mathrm{Q}_{\mathrm{t}-1}, \mathrm{Q}_{\mathrm{t}-2,}, \mathrm{P}_{\mathrm{t}}, \mathrm{P}_{\mathrm{t}-1}, \mathrm{P}_{\mathrm{t}-2,}, \mathrm{P}_{\mathrm{t}-3}$ & MMF & 0.7759 & 0.8809 & 0.6957 & 0.8341 & 0.8181 & 0.9045 & 0.6493 & 0.8058 \\
\hline $\mathrm{Q}_{\mathrm{t}}, \mathrm{Q}_{\mathrm{t}-1}, \mathrm{Q}_{\mathrm{t}-2,}, \mathrm{Q}_{\mathrm{t}-3}, \mathrm{P}_{\mathrm{t}}, \mathrm{P}_{\mathrm{t}-1}, \mathrm{P}_{\mathrm{t}-2}, \mathrm{P}_{\mathrm{t}-3}$ & & 0.7958 & 0.8921 & 0.7037 & 0.8389 & 0.8421 & 0.9177 & 0.6927 & 0.8323 \\
\hline $\mathrm{Q}_{\mathrm{t}}, \mathrm{Q}_{\mathrm{t}-1}, \mathrm{Q}_{\mathrm{t}-2}, \mathrm{Q}_{\mathrm{t}-3}, \mathrm{Q}_{\mathrm{t}-4}, \mathrm{P}_{\mathrm{t}}, \mathrm{P}_{\mathrm{t}-1}, \mathrm{P}_{\mathrm{t}-2}, \mathrm{P}_{\mathrm{t}-3}$ & & 0.8199 & 0.9055 & 0.7346 & 0.8571 & 0.8768 & 0.9364 & 0.7094 & 0.8423 \\
\hline $\mathrm{Q}_{\mathrm{t}}, \mathrm{P}_{\mathrm{t},} \mathrm{P}_{\mathrm{t}-1}, \mathrm{P}_{\mathrm{t}-2,}, \mathrm{P}_{\mathrm{t}-3}$ & & 0.5378 & 0.7334 & 0.5336 & 0.7305 & 0.6486 & 0.8054 & 0.5415 & 0.7359 \\
\hline $\mathrm{Q}_{\mathrm{t}}, \mathrm{Q}_{\mathrm{t}-1}, \mathrm{P}_{\mathrm{t}}, \mathrm{P}_{\mathrm{t}-1}, \mathrm{P}_{\mathrm{t}-2}, \mathrm{P}_{\mathrm{t}-3}$ & & 0.6575 & 0.8109 & 0.5789 & 0.7609 & 0.6997 & 0.8365 & 0.5628 & 0.7502 \\
\hline $\mathrm{Q}_{\mathrm{t}}, \mathrm{Q}_{\mathrm{t}-1}, \mathrm{Q}_{\mathrm{t}-2,}, \mathrm{P}_{\mathrm{t}}, \mathrm{P}_{\mathrm{t}-1}, \mathrm{P}_{\mathrm{t}-2,}, \mathrm{P}_{\mathrm{t}-3}$ & MLR & 0.7118 & 0.8437 & 0.6091 & 0.7804 & 0.7694 & 0.8772 & 0.5942 & 0.7709 \\
\hline $\mathrm{Q}_{\mathrm{t}}, \mathrm{Q}_{\mathrm{t}-1}, \mathrm{Q}_{\mathrm{t}-2,}, \mathrm{Q}_{\mathrm{t}-3}, \mathrm{P}_{\mathrm{t}}, \mathrm{P}_{\mathrm{t}-1}, \mathrm{P}_{\mathrm{t}-2}, \mathrm{P}_{\mathrm{t}-3}$ & & 0.7461 & 0.8638 & 0.6631 & 0.8143 & 0.7981 & 0.8934 & 0.6419 & 0.8012 \\
\hline $\mathrm{Q}_{\mathrm{t}}, \mathrm{Q}_{\mathrm{t}-1}, \mathrm{Q}_{\mathrm{t}-2}, \mathrm{Q}_{\mathrm{t}-3}, \mathrm{Q}_{\mathrm{t}-4}, \mathrm{P}_{\mathrm{t}}, \mathrm{P}_{\mathrm{t}-1}, \mathrm{P}_{\mathrm{t}-2}, \mathrm{P}_{\mathrm{t}-3}$ & & 0.7651 & 0.8747 & 0.7231 & 0.8503 & 0.8251 & 0.9084 & 0.6611 & 0.8131 \\
\hline
\end{tabular}

Table 5. Performance consequences of simulation five.

\begin{tabular}{|c|c|c|c|c|c|c|c|c|c|}
\hline \multirow[b]{2}{*}{ INPUTS } & \multirow[b]{2}{*}{ Model } & \multicolumn{2}{|c|}{ FFBPN } & \multicolumn{2}{|c|}{ CFBPN } & \multicolumn{2}{|c|}{ RNN } & \multicolumn{2}{|c|}{ RBFN } \\
\hline & & $\mathrm{E}_{\mathrm{NS}}$ & $\mathrm{R}^{2}$ & $\mathrm{E}_{\mathrm{NS}}$ & $\mathrm{R}^{2}$ & $\mathrm{E}_{\mathrm{NS}}$ & $\mathrm{R}^{2}$ & $\mathrm{E}_{\mathrm{NS}}$ & $\mathrm{R}^{2}$ \\
\hline $\mathrm{Q}_{\mathrm{t}}, \mathrm{P}_{\mathrm{t}}, \mathrm{P}_{\mathrm{t}-1}, \mathrm{P}_{\mathrm{t}-2,}, \mathrm{P}_{\mathrm{t}-3}, \mathrm{P}_{\mathrm{t}-4}$ & & 0.6702 & 0.8187 & 0.5933 & 0.7703 & 0.7628 & 0.8734 & 0.5689 & 0.7543 \\
\hline $\mathrm{Q}_{\mathrm{t}}, \mathrm{Q}_{\mathrm{t}-1}, \mathrm{P}_{\mathrm{t}}, \mathrm{P}_{\mathrm{t}-1}, \mathrm{P}_{\mathrm{t}-2}, \mathrm{P}_{\mathrm{t}-3}, \mathrm{P}_{\mathrm{t}-4}$ & & 0.7359 & 0.8579 & 0.6533 & 0.8083 & 0.7899 & 0.8888 & 0.5803 & 0.7618 \\
\hline $\mathrm{Q}_{\mathrm{t}}, \mathrm{Q}_{\mathrm{t}-1}, \mathrm{Q}_{\mathrm{t}-2}, \mathrm{P}_{\mathrm{t}}, \mathrm{P}_{\mathrm{t}-1}, \mathrm{P}_{\mathrm{t}-2}, \mathrm{P}_{\mathrm{t}-3}, \mathrm{P}_{\mathrm{t}-4}$ & $\mathrm{SRC}$ & 0.7818 & 0.8842 & 0.6686 & 0.8177 & 0.8128 & 0.9016 & 0.6440 & 0.8025 \\
\hline $\mathrm{Q}_{\mathrm{t}}, \mathrm{Q}_{\mathrm{t}-1}, \mathrm{Q}_{\mathrm{t}-2,}, \mathrm{Q}_{\mathrm{t}-3}, \mathrm{P}_{\mathrm{t}}, \mathrm{P}_{\mathrm{t}-1}, \mathrm{P}_{\mathrm{t}-2}, \mathrm{P}_{\mathrm{t}-3}, \mathrm{P}_{\mathrm{t}-4}$ & & 0.7999 & 0.8944 & 0.7218 & 0.8496 & 0.8394 & 0.9162 & 0.6958 & 0.8342 \\
\hline $\mathrm{Q}_{\mathrm{t}}, \mathrm{Q}_{\mathrm{t}-1}, \mathrm{Q}_{\mathrm{t}-2,}, \mathrm{Q}_{\mathrm{t}-3}, \mathrm{Q}_{\mathrm{t}-4}, \mathrm{P}_{\mathrm{t}}, \mathrm{P}_{\mathrm{t}-1}, \mathrm{P}_{\mathrm{t}-2}, \mathrm{P}_{\mathrm{t}-3}, \mathrm{P}_{\mathrm{t}-4}$ & & 0.8193 & 0.9052 & 0.7605 & 0.8721 & 0.8804 & 0.9383 & 0.7221 & 0.8498 \\
\hline $\mathrm{Q}_{\mathrm{t}}, \mathrm{P}_{\mathrm{t},} \mathrm{P}_{\mathrm{t}-1}, \mathrm{P}_{\mathrm{t}-2}, \mathrm{P}_{\mathrm{t}-3}, \mathrm{P}_{\mathrm{t}-4}$ & & 0.7069 & 0.8408 & 0.6372 & 0.7983 & 0.7766 & 0.8813 & 0.6236 & 0.7897 \\
\hline $\mathrm{Q}_{\mathrm{t}}, \mathrm{Q}_{\mathrm{t}-1}, \mathrm{P}_{\mathrm{t}}, \mathrm{P}_{\mathrm{t}-1}, \mathrm{P}_{\mathrm{t}-2,}, \mathrm{P}_{\mathrm{t}-3,}, \mathrm{P}_{\mathrm{t}-4}$ & & 0.7485 & 0.8652 & 0.6638 & 0.8148 & 0.8083 & 0.8991 & 0.6310 & 0.7944 \\
\hline $\mathrm{Q}_{\mathrm{t}}, \mathrm{Q}_{\mathrm{t}-1,}, \mathrm{Q}_{\mathrm{t}-2,}, \mathrm{P}_{\mathrm{t}}, \mathrm{P}_{\mathrm{t}-1}, \mathrm{P}_{\mathrm{t}-2}, \mathrm{P}_{\mathrm{t}-3}, \mathrm{P}_{\mathrm{t}-4}$ & MMF & 0.8024 & 0.8958 & 0.7114 & 0.8435 & 0.8423 & 0.9178 & 0.6575 & 0.8109 \\
\hline $\mathrm{Q}_{\mathrm{t}}, \mathrm{Q}_{\mathrm{t}-1}, \mathrm{Q}_{\mathrm{t}-2}, \mathrm{Q}_{\mathrm{t}-3}, \mathrm{P}_{\mathrm{t}}, \mathrm{P}_{\mathrm{t}-1}, \mathrm{P}_{\mathrm{t}-2}, \mathrm{P}_{\mathrm{t}-3}, \mathrm{P}_{\mathrm{t}-4}$ & & 0.8132 & 0.9018 & 0.7308 & 0.8549 & 0.8551 & 0.9247 & 0.7202 & 0.8487 \\
\hline $\mathrm{Q}_{\mathrm{t}}, \mathrm{Q}_{\mathrm{t}-1}, \mathrm{Q}_{\mathrm{t}-2,}, \mathrm{Q}_{\mathrm{t}-3}, \mathrm{Q}_{\mathrm{t}-4}, \mathrm{P}_{\mathrm{t}}, \mathrm{P}_{\mathrm{t}-1}, \mathrm{P}_{\mathrm{t}-2}, \mathrm{P}_{\mathrm{t}-3}, \mathrm{P}_{\mathrm{t}-4}$ & & 0.8308 & 0.9115 & 0.7684 & 0.8766 & 0.8975 & 0.9474 & 0.7243 & 0.8511 \\
\hline $\mathrm{Q}_{\mathrm{t}}, \mathrm{P}_{\mathrm{t},} \mathrm{P}_{\mathrm{t}-1}, \mathrm{P}_{\mathrm{t}-2}, \mathrm{P}_{\mathrm{t}-3}, \mathrm{P}_{\mathrm{t}-4}$ & & 0.6326 & 0.7954 & 0.5795 & 0.7613 & 0.6567 & 0.8104 & 0.5541 & 0.7444 \\
\hline $\mathrm{Q}_{\mathrm{t}}, \mathrm{Q}_{\mathrm{t}-1}, \mathrm{P}_{\mathrm{t}}, \mathrm{P}_{\mathrm{t}-1}, \mathrm{P}_{\mathrm{t}-2,}, \mathrm{P}_{\mathrm{t}-3}, \mathrm{P}_{\mathrm{t}-4}$ & & 0.6742 & 0.8211 & 0.6291 & 0.7932 & 0.7162 & 0.8463 & 0.5754 & 0.7586 \\
\hline $\mathrm{Q}_{\mathrm{t}}, \mathrm{Q}_{\mathrm{t}-1,}, \mathrm{Q}_{\mathrm{t}-2,}, \mathrm{P}_{\mathrm{t}}, \mathrm{P}_{\mathrm{t}-1}, \mathrm{P}_{\mathrm{t}-2,}, \mathrm{P}_{\mathrm{t}-3}, \mathrm{P}_{\mathrm{t}-4}$ & MLR & 0.7359 & 0.8579 & 0.6451 & 0.8032 & 0.7800 & 0.8832 & 0.6255 & 0.7909 \\
\hline$Q_{t}, Q_{t-1}, Q_{t-2}, Q_{t-3}, P_{t}, P_{t-1}, P_{t-2}, P_{t-3}, P_{t-4}$ & & 0.7591 & 0.8713 & 0.6932 & 0.8326 & 0.8197 & 0.9054 & 0.6702 & 0.8187 \\
\hline $\mathrm{Q}_{\mathrm{t}}, \mathrm{Q}_{\mathrm{t}-1}, \mathrm{Q}_{\mathrm{t}-2}, \mathrm{Q}_{\mathrm{t}-3}, \mathrm{Q}_{\mathrm{t}-4}, \mathrm{P}_{\mathrm{t}}, \mathrm{P}_{\mathrm{t}-1}, \mathrm{P}_{\mathrm{t}-2}, \mathrm{P}_{\mathrm{t}-3}, \mathrm{P}_{\mathrm{t}-4}$ & & 0.7841 & 0.8855 & 0.7588 & 0.8711 & 0.8449 & 0.9192 & 0.6945 & 0.8334 \\
\hline
\end{tabular}

result is obtained. The best result in this simulation is shown by MMF model when trained in a RNN with $\mathrm{R}^{2}$ value as 0.9474 . Whereas, the corresponding $R^{2}$ value when trained in the same network, in power model and MLR are 0.9383 and 0.9192, respectively. In case of FFBPN, CFBPN, RBFN best value of $\mathrm{R}^{2}$ are $0.9115,0.8766$, and 0.8511 for MMF model, respectively. While discharge $t$, $\mathrm{t}-1, \mathrm{t}-2, \mathrm{t}-3$ and $\mathrm{t}-4$ day's along with rainfall of day's $\mathrm{t}$, $\mathrm{t}-1, \mathrm{t}-2$, and $\mathrm{t}-3$ are considered as inputs, best value of $\mathrm{R}^{2}$ so obtained is 0.9364 in MMF model when trained in RNN algorithm but with SRC and the MLR, when trained in the same algorithm, the coefficient of determination values are 0.9295 and 0.9084 successively for simulation two. For
FFBPN, CFBPN, RBFN best value of $\mathrm{R}^{2}$ are 0.9115 , 0.8766 , and 0.8511 whereas considering MMF model. Actual verses predicted sediment load for all simulation are presented in figure 7.

Discharge $\mathrm{t}, \mathrm{t}-1, \mathrm{t}-2, \mathrm{t}-3$ and $\mathrm{t}-4$ day's along with rainfall of day's $t, t-1$, and $t-2$ are considered as inputs for simulation three, the network yields the best result in establishing the association between sediment load and discharge with $\mathrm{R}^{2}$ as 0.9153 in $\mathrm{MMF}$ model, while the corresponding value in power model and MLR are 0.9142 and 0.8174 , respectively. In case of FFBPN, CFBPN, RBFN best value of $\mathrm{R}^{2}$ for MMF model are $0.8952,0.8364$, and 0.8292 , respectively. For simulation four discharge $t$, 


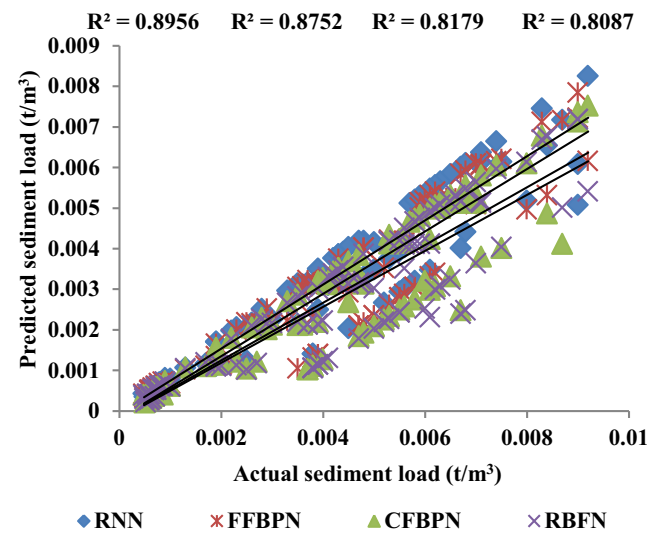

(a)

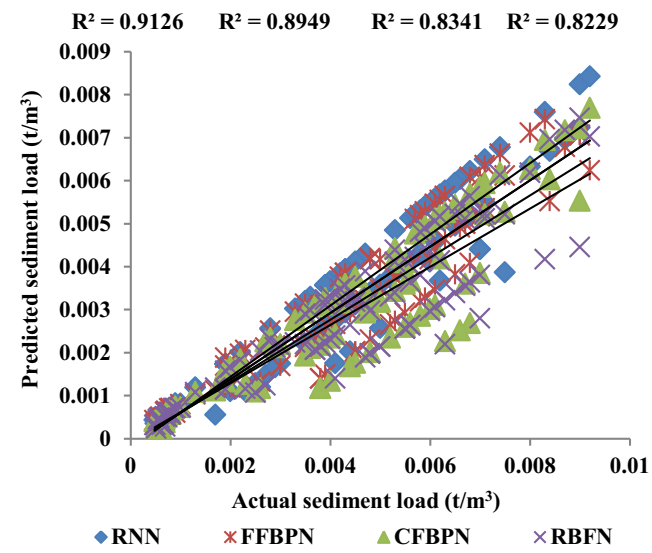

(c)

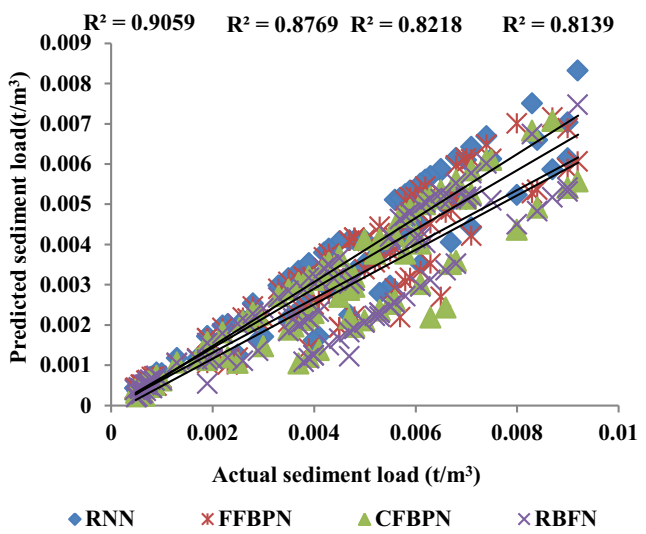

(b)

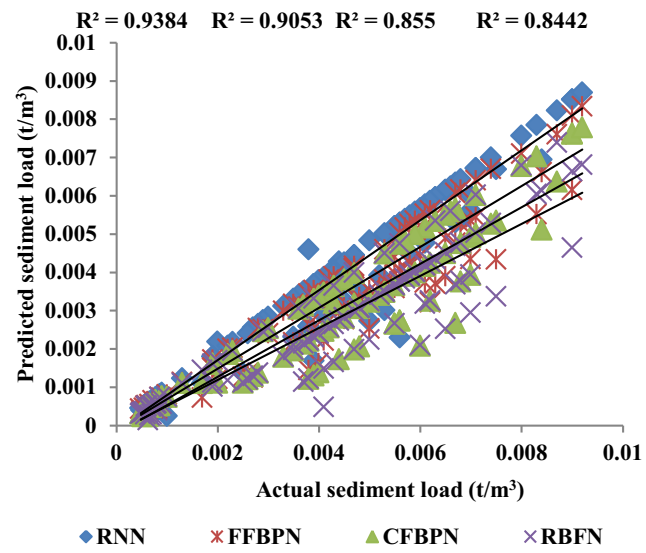

(d)

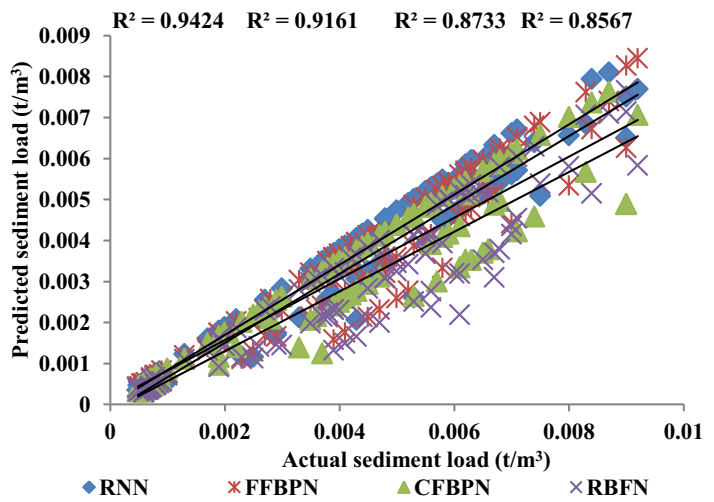

(e)

Figure 8. Actual vs predicted sediment concentration for (a) simulation one, (b) simulation two, (c) simulation three, (d) simulation four and (e) simulation five.

$\mathrm{t}-1, \mathrm{t}-2, \mathrm{t}-3$ and $\mathrm{t}-4$ day's along with rainfall of day's $\mathrm{t}$, and $t-1$ is feed as inputs, then best result is obtained by training the inputs in RNN algorithm with the model efficiency 0.9039 for MMF model. But in case of SRC and MLR model best value of $\mathrm{R}^{2}$ is 0.8991 and 0.8617 . Best values of $\mathrm{R}^{2}$ for MMF model are 0.8763, 0.8226, and 0.8168 for FFBPN, CFBPN, and RBFN, respectively. While daily discharge and present day rainfall as input, model performs best with $\mathrm{R}^{2}$ value as 0.8977 when trained RNN algorithm, while the corresponding values in power model and MLR are 0.8862 and 0.8573 , respectively (figure 8).

\section{Conclusions}

In this work, sediment concentration is predicted with various combinations of discharge, and precipitation for present day and lag period of daily data during monsoon period. Four algorithms, FFBP, CFFBP, RNN and RBF via 
SRC, MMF and MLR models are experimented to develop the performance of models. Here the works have been completed through consideration of five series of inputs with (1) discharge and present day rainfall, (2) discharge and up to one day lag rainfall, (3) discharge and up to two day lag rainfall, (4) discharge and rainfall up to three lag rainfall and (5) discharge and rainfall up to four previous days as input. Among the three models which are used to search the association of precipitation, discharge and suspended sediment, it is concluded that an MMF model of RNN achieves better compared to power model (SRC) and MLR model than the other three algorithms. Most of the studies in the literature put solution to MLR algorithms feeded to ANN whereas a step has been taken here to compare the results with MMF and SRC to get improved model. Based on the results of the study, the MMF model is found to be superior as compared to other two models in four algorithms. The methods proposed in this study are to be used in the process of obtaining a feasible solution for finding sediment load of watersheds for arid region.

\section{References}

[1] Nourani V, Komasi M and Mano A 2009 A multivariate ANN-wavelet approach for rainfall-runoff modelling. Water Resources Management 23(14): 2877-2894 https://doi.org/ 10.1007/s11269-009-9414-5

[2] Kisi O 2004 Multi-layer perceptrons with Levenberg Marquardt training algorithm for suspended sediment concentration prediction and estimation. Hydrological Sciences Journal 49(6): 1025-1040 https://doi.org/10.1623/hysj.49.6. 1025.55720

[3] Minns A W and Hall M J 1996 Artificial neural networks as rainfall runoff models. Hydrological Science Journal 41(3): 399-417

[4] Fernando D A K and Jayawardena A W 1998 Runoff forecasting using RBF networks with OLS algorithm. Journal of Hydrologic Engineering 3(3): 203-209 https://doi.org/10. 1061/(asce)1084-0699(1998)3:3(203)

[5] Cigizoglu H K 2003 Incorporation of ARMA models into flow forecasting by artificial neural networks. Environmetrics 14(4): 417-427 https://doi.org/10.1002/env.596

[6] Cigizoglu H K 2003b Estimation, forecasting and extrapolation of flow data by artificial neural networks. Hydrological Sciences Journal 48(3): 349-361 https://doi.org/10.2112/06742.1
[7] Jain S K 2001 Development of integrated sediment rating curves using ANNs. Journal of Hydraulic Engineering (ASCE) 127(1): 30-37 https://doi.org/10.1061/(asce)07339429(2001)127:1(30)

[8] Cigizoglu H K 2002c Suspended sediment estimation for rivers using artificial neural networks and sediment rating curves. Turkish Journal of Engineering and Environmental Sciences 26(1): 27-36 https://doi.org/10.1061/ 40685(2003)173

[9] Fang H W, Lai R X, Lin B L, Xu X Y, Zhang F X and Zhang Y F 2016 Variational-Based Data Assimilation to Simulate Sediment Concentration in the Lower Yellow River, China. J. Hydrologic Engineering 21(5): 04016010: 1-11

[10] Merritt W S, Letcher R A, Jakeman A J 2003 A review of erosion and sediment transport models. Environmental Modeling and Software 18(8-9): 761-799 https://doi.org/10. 1016/s1364-8152(03)00078-1

[11] Agarwal A, Singh R D, Mishra S K, Bhunya P K 2005 ANN based sediment yield models for Vamsadhara river basin (India). Water SA 31(1): 95-100

[12] Luk K C, Ball J E and Sharma A 2001 An application of artificial neural networks for rainfall forecasting. Journal of Math. Computer Model. 33:683-693 https://doi.org/10.1007/ s11633-016-0986-2

[13] Hidayat H, Hoitink A J F, Sassi M G and Torfs P J J F 2014 Prediction of Discharge in a Tidal River Using Artificial Neural Networks. J. Hydrologic Engineering 19(8): 04014006: 1-8

[14] Singh V P, Cui H and Byrd A 2015 Sediment graphs based on entropy theory. J. Hydrologic Engineering 20(6):C4014004:1-10

[15] Kumar D, Pandey A, Sharma N and Flügel W A 2015 Modeling suspended sediment using artificial neural networks and TRMM-3B42 version 7 rainfall dataset. $J$. Hydrologic Engineering 20(6): 1-12

[16] Ghose D K and Samantaray S 2018 Modelling sediment concentration using back propagation neural network and regression coupled with genetic algorithm. Procedia Computer Science 125: 85-92

[17] Rajaee T, Nourani V, Zounemat-Kermani M and Kisi O 2011 River suspended sediment load prediction: application of ANN and wavelet conjunction model. J. Hydrologic Engineering 16(8): 613-627

[18] Ghose D K and Samantaray S 2019 Sedimentation process and its assessment through integrated sensor network and machine learning process. Computational intelligence in sensor network. 776: 473-488, Springer, Berlin, Heidelberg

[19] Samantaray S and Ghose D K 2018 Evaluation of suspended sediment concentration using descent neural networks. Procedia Computer Science 132: 1824-1831 